\title{
Assessing area and volume changes from deglaciated areas, Valle d'Aosta, Italy
}

\author{
Ghiara Vanuzzo, Manuela Pelfini \\ Dipartimento di Scienze dell'Ambiente e del Territorio, Università di Milano, I-20126 Milano, Italy
}

\begin{abstract}
This paper assesses the amount of area and volume retreat, from the maximum expansion phase of the Little Ice Age to date, of glaciers at the head of Valpelline and Valtournenche (Valle d'Aosta, western Alps, Italy) using field survey, air-photo interpretation, analysis of historical records and a geographical information system. The calculated areal retreat value is $42.34 \%$. For the upper Valpelline glaciers, the area declined from $20.13 \mathrm{~km}^{2}$ to $14.78 \mathrm{~km}^{2}$; whereas for the upper Valtournenche glaciers, a loss of $14.78 \mathrm{~km}^{2}$ to $5.8 \mathrm{~km}^{2}$ has been recorded. The estimated ice-volume loss was $0.35 \mathrm{~km}^{3}$.
\end{abstract}

\section{INTRODUCTION}

Owing to their sensitivity to climate changes, Alpine glaciers are considered among the most important palaeoclimatic indicators. The dynamic response of glaciers is controlled by the energy and mass budgets. The latter, in temperate regions, depends on the temperature of the ablation season and on snowfall. The data obtainable from glacial deposits allow continuous or discontinuous temporal sequences of glacial changes to be reconstructed, so that both direction and intensity of climate changes may be deduced.

Many investigations have been carried out on the Alpine chain, both in the past and present, in order to better understand the glaciers' patterns of response and collect more information on climate change (Ahlmann, 1953; Hoinkes, 1968; Kuhn, 1981; Haeberli and others, 1989; Oerlemans, 1989; Maisch, 1992; Haeberli, 1995).

In this research, the period considered for assessing area and volume changes is from the maximum extent of the Little Ice Age (LIA) up to the present. In the Valle d'Aosta (western Alps, Italy), the LIA peaked in 1820, according to Vanni (1939) and Orombelli and Porter (1982). The presentday reference is taken as 1981.

The LIA corresponds to the latest phase of Neoglacial expansion attained by mountain glaciers (Porter and Denton, 1967): it was coeval in most parts of the Earth in response to a climate change that, although limited, had a global effect (Porter, 1986; Röthlisberger, 1986). For many glaciers in the Alps and Northern Hemisphere, this advance was the greatest of the Holocene (Porter, 1981, 1986; Nesje and others, 1991). Also, in the Southern Hemisphere, the LIA advance is indicated as the "major episode of glacier expansion" (Porter, 1975) during the Neoglacial. The beginning of the LIA, which was preceded by the Medieval Warm Period, may be placed between the 13 th and the 14 th centuries AD, whereas its climax took place between the mid-16th and the mid-19th centuries (Grove, 1988).

The aim of this research was to assess the area and volume of glacier retreat at the head of Valpelline and Valtournenche (Valle d'Aosta) by interpreting deglaciated landforms and with the help of a geographical information system (GIS).

\section{REGONSTRUGTION OF LIA ICE EXTENT}

Reconstruction of the maximum expansion attained by glaciers during the LIA was carried out using field survey, airphoto interpretation and analysis of historical records. The mapping data thus collected were computerized and analyzed with a GIS. Different programs have been used. Both the present and the LIA extent and topography of every glacier has been digitized. Each map with glaciers has been georeferenced. In this way, data on glaciated areas at the maximum phase of the LIA expansion and at present were obtained. Furthermore, by comparing the present topography with the LIA reconstruction, the difference in ice volume between the LIA glaciers and the present situation was assessed. However, it was only possible to obtain data on the volume difference since no information was available on the depth of the bedrock and therefore on the ice thickness.

\section{THE VALPELLINE GLACIERS}

The glaciers located at the head of Valpelline from west to east are the following: Mont Braulè, Tza de Tzan, Grandes Murailles, Petites Murailles, Dames, Bellatzà and Solatsèt (Fig. 1). Of all these glaciers, those which have aroused the greatest interest among researchers are the Tza de Tzan and Grandes Murailles, for which the most abundant documentation also exists. The Tza de Tzan and Grandes Murailles glaciers occupy the great terminal cirque of Valpelline. At present, both their fronts and firn fields are separate. The data available from literature show that, in the Middle Ages, the extent of these two glaciers was more limited: many mountain passes, no longer open today, were used in the Middle Ages (Röthlisberger, 1974; Vanni, 1939); also the altitude limit for farming practices and human settlements was higher than today (Vanni, 1939; Revelli, 1917). These conditions must have lasted until the mid-17th century since, from this period onwards, the valley was affected by a decline in road practicability and in the number of inhabitants. A phase of climate deterioration began, causing the termini of Tza de Tzan and Grandes Murailles glaciers to 


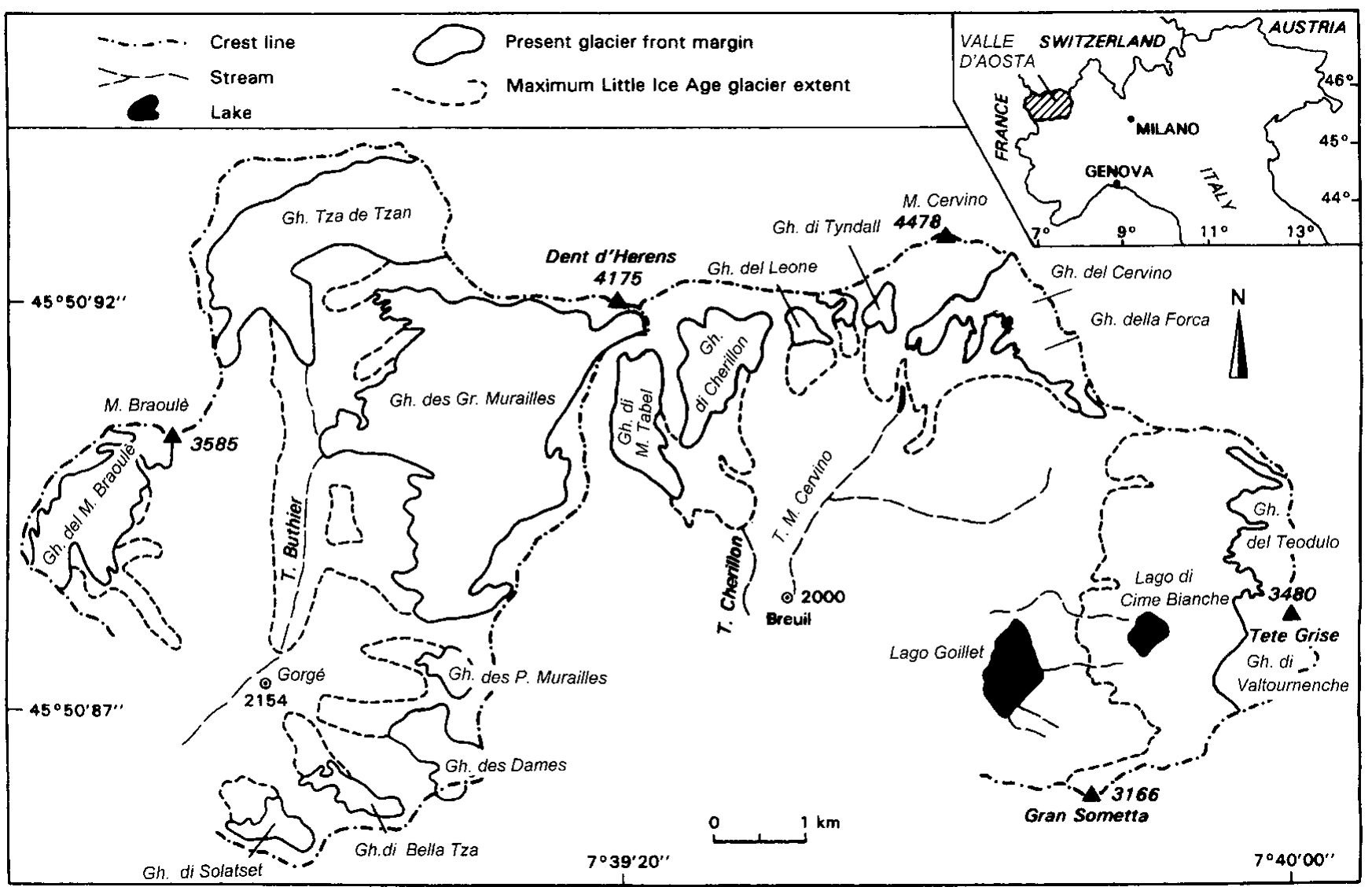

Fig. 1. Locations of glaciers studied in upper Valpelline and Valtournenche.

converge and extend as far as the rock step overhanging Alpe Gorgé (2156 m) (Fig. 1).

Today, the valley is free from ice and has a characteristic and imposing U-shaped profile (Fig. 2). On the valley side there is a trimline. The lower part of the slope is covered by heterogeneous glacial deposits and the upper part by continuous vegetation. This line indicates the vertical extent of the Tza de Tzan glacier that was nearly $200 \mathrm{~m}$ thick during the LIA maximum. The valley floor is covered by a continuous till deposit, showing different degrees of colonization by vegetation.

The separation of the Grandes Murailles and Tza de

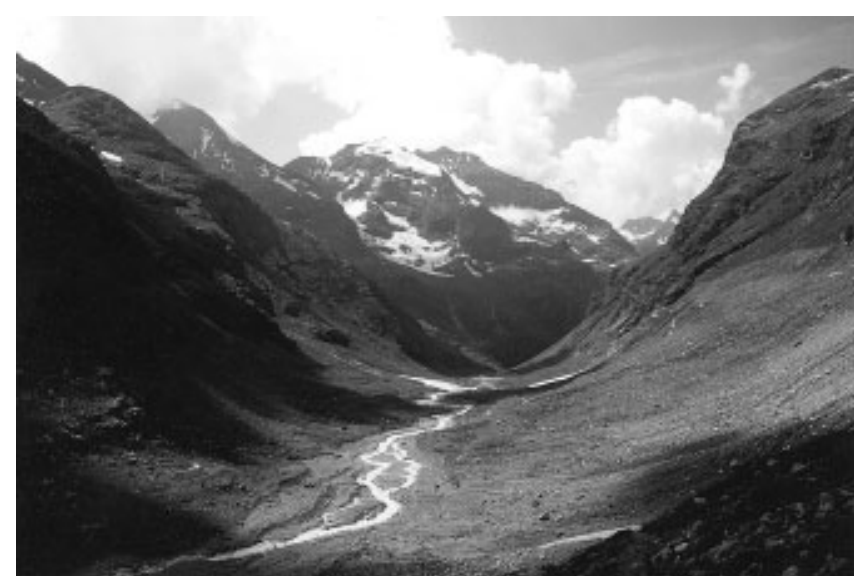

Fig. 2. U-profile of upper Valpelline after retreat of $T$ za de Tzan glacier. Trimline is clearly visible on right; line between lower slope covered with heterogeneous glacial deposits and upper part covered with continuous vegetation (photo by $C$. Vanuzzo).
Tzan glaciers was reported by Frisa (1956), and by 1965 they were described as separate entities (Vanni, 1966). Figures 3 and 4 show the considerable recession at the confluence zone of the two glaciers from the end of the last century to 1994. At present, the right-hand lateral moraine of the Grandes Murailles glacier is the only remnant of the ancient ice which once covered this valley. Figure 5 shows the dynamic aspects of the two glaciers' fronts based on data collected by Italian researchers early in the 20th century: both glaciers show a progressive retreat and record the moderate positive fluctuation of the 1970s and 1980s, which started respectively in 1968 for the Grandes Murailles and in 1971 for the Tza de Tzan glaciers.

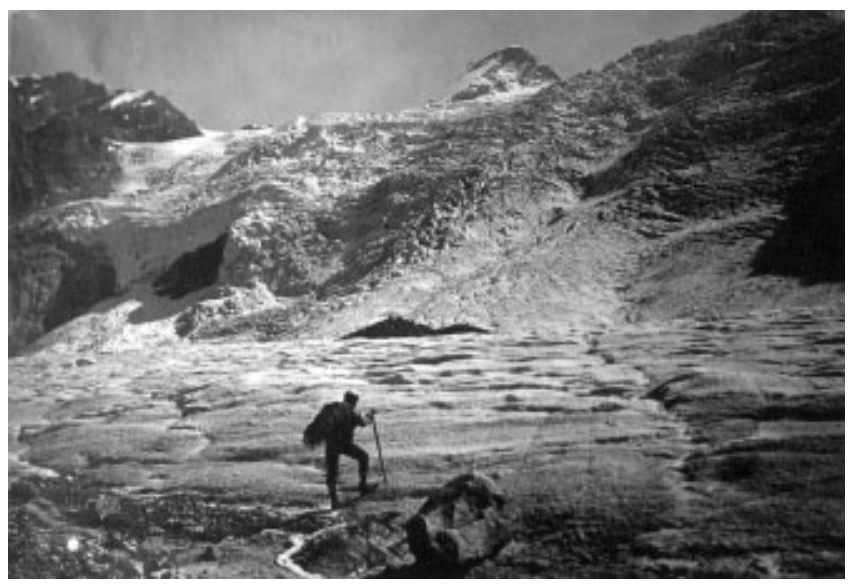

Fig. 3. Confluence of the Grandes Murailles and T za de Tzan glaciers between the end of the 19th and beginning of the 20th centuries (photo by Ferrari, property of "Fondazione Sella", Biella, Italy). The T za de T zan flows from left to right. 


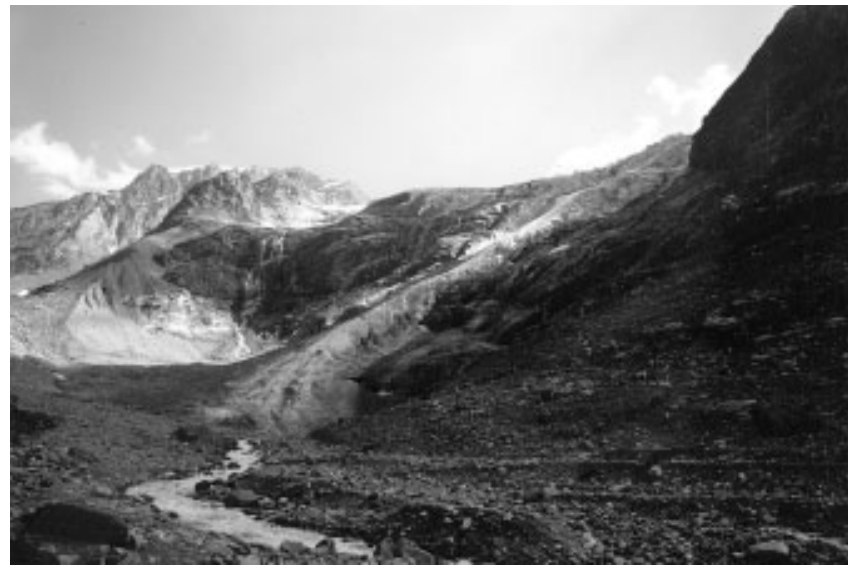

Fig. 4. Approximately the same view as Figure 3 in summer 1994 (photo by C.Vanuzzo). The right moraine of the Grandes Murailles glacier, which flowed into the $T$ za de Tzan glacier until the middle of this century to form the Ghiacciaio di $T$ za de Tzan Inferiore, is visible. This area is now ice-free. The snout of $T$ za de $T$ zan glacier is more withdrawn (left of the photo).

\section{THE VALTOURNENGHE GLAGIERS}

From west to east, the Valtournenche glaciers are as follows: Mont Tabel, Cherillon, Leone (Inferiore and Superiore), Tyndall, Cervino (Matterhorn), Forca, Teódulo and Valtournenche (Fig. 1). The Valtournenche and Teódulo glaciers are broad, with a low inclination at the foot of the crest stretching from Tête du Breuil (3467 m) as far as the boundary with the Ventina glacier. The historical data available on the Valtournenche glacier show that in Roman and Medieval times the ice cover was less than today (Lesca and others, 1955), as was the case with the Tza de Tzan glacier. A new phase of glacial advance has been described starting in the mid-18th century;

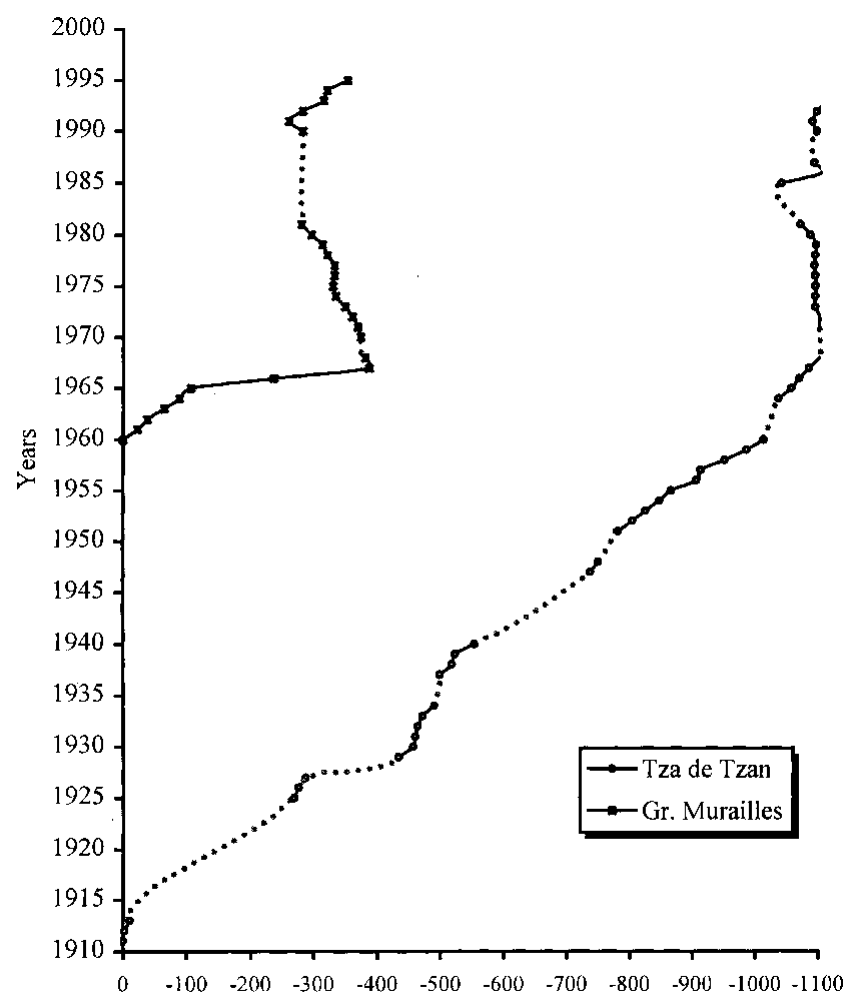

$\mathrm{m}$

Fig. 5. Recession of the Tza de Tzan and Grandes Murailles glaciers. The dotted line represents missing data. all the 19th century maps particularly depict the glaciers of this area as very large (Lesca and others, 1955).

Evidence of the LIA advance phase is the presence of chaotically deposited till, seldom arranged in morainic ridges, in the proglacial area; clasts are heterogeneous and range from a few centimetres to $1-2 \mathrm{~m}$, with scarce or sometimes no lichen cover. The boundary between the till and the Alpine tundra, which was unaffected by the glacier during the Holocene, is quite visible. A fluted-moraine forefield can be seen on aerial photographs which do not show the patterned ground that can be seen in the field, such as sorted stone circles, $1-2 \mathrm{~m}$ in diameter. In the proglacial area, numerous small glacial lakes are found, formed after the gradual glacier retreat; the largest is Lago di Cime Bianche (2804 ma.s.l.) created in 1934. Data on fluctuations of Valtournenche glacier, from the early 1900s onwards, are summarized in Figure 6.

The Mont Tabel and Cherillon glaciers are found on the western slope of Valtournenche. Their fronts, united during the maximum LIA expansion, deposited an impressive semicircular moraine (Fig. 7). The fluctuations of these two glaciers have been reconstructed and are also shown in Figure 6.

\section{GHANGES IN THE AREA OF THE VALPELLINE AND VALTOURNENGHE GLAGIERS}

The Valpelline glaciers have lost $29.21 \%$ of their area since the LIA maximum, from $20.13 \mathrm{~km}^{2}$ during the LIA, to $14.25 \mathrm{~km}^{2}$ today, a reduction of $5.88 \mathrm{~km}^{2}$ (Table 1). Using data from Vanni and others (1953), it was possible to reconstruct some of the recessional stages of the Mont Braulè, Tza de Tzan and Petites Murailles glaciers (Fig. 8).

The overall retreat of glaciers at the head of Valtournenche was greater than that which affected those in Valpel-

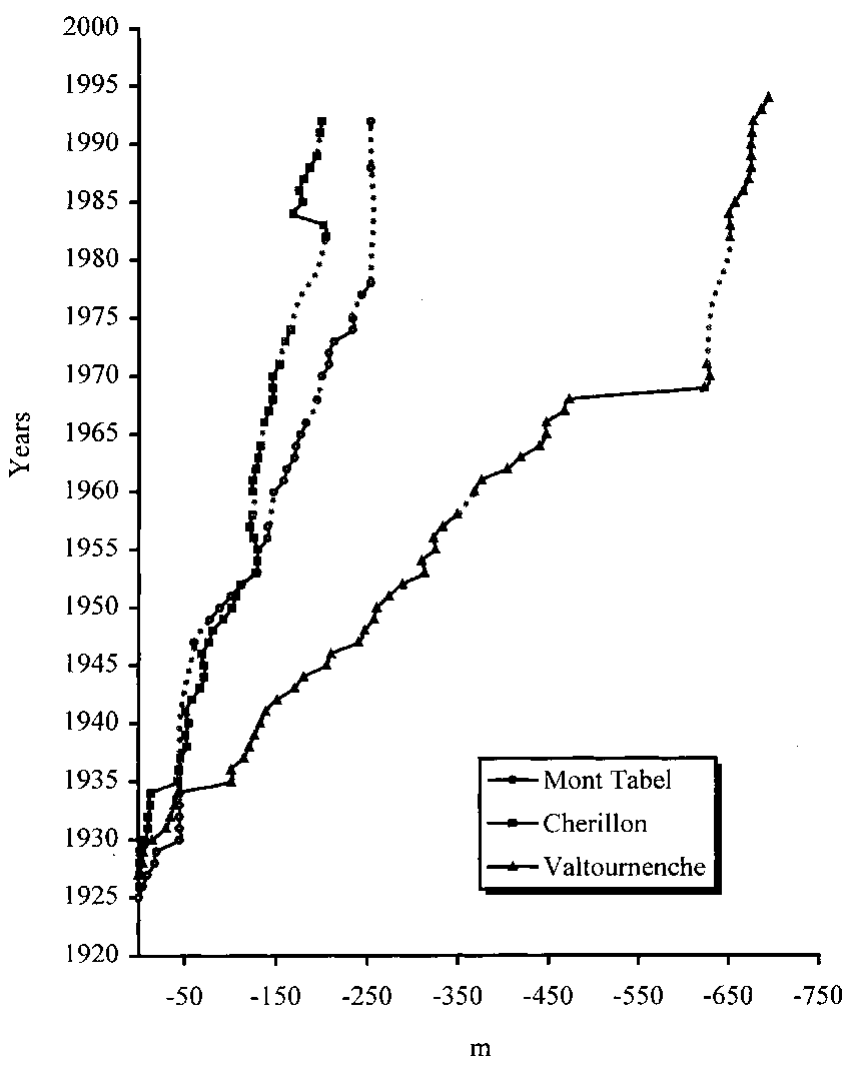

Fig. 6. Recession of Valtournenche, Mont Tabel and Cherillon glaciers. The dotted line represents mising data. 
Table 1. Changes in area of the Valpelline glaciers

\begin{tabular}{|c|c|c|c|c|c|}
\hline \multirow[t]{3}{*}{ Glaciers } & \multirow[t]{3}{*}{ Orientation } & \multicolumn{2}{|c|}{ Extent of glaciers } & \multicolumn{2}{|c|}{ Loss of area since $L I A$} \\
\hline & & $L I A$ & Present & & \\
\hline & & $\mathrm{km}^{2}$ & $\mathrm{~km}^{2}$ & $\mathrm{~km}^{2}$ & $\%$ \\
\hline Ghiacciaio del Mont Braulè & SE & 2.21 & 1.63 & 0.58 & 26.24 \\
\hline Ghiacciaio di Tza de Tzan* ${ }^{*}$ & SW & 15.13 & 3.75 & 4.08 & 26.97 \\
\hline Ghiacciaio des Grandes Murailles* & SW & & 7.30 & & \\
\hline Ghiacciaio des Petites Murailles & $\mathrm{W}$ & 0.54 & 0.23 & 0.31 & 57.41 \\
\hline Ghiacciaio des Dames & $\mathrm{W}$ & 1.09 & 0.68 & 0.41 & 37.61 \\
\hline Ghiacciaio di Bellatzà & NW & 0.63 & 0.30 & 0.33 & 52.38 \\
\hline Ghiacciaio di Solatsét & NW & 0.53 & 0.36 & 0.17 & 32.07 \\
\hline Total & & 20.13 & 14.25 & 5.88 & 29.21 \\
\hline
\end{tabular}

Note: These glaciers were joined during the LIA, but are now separate.

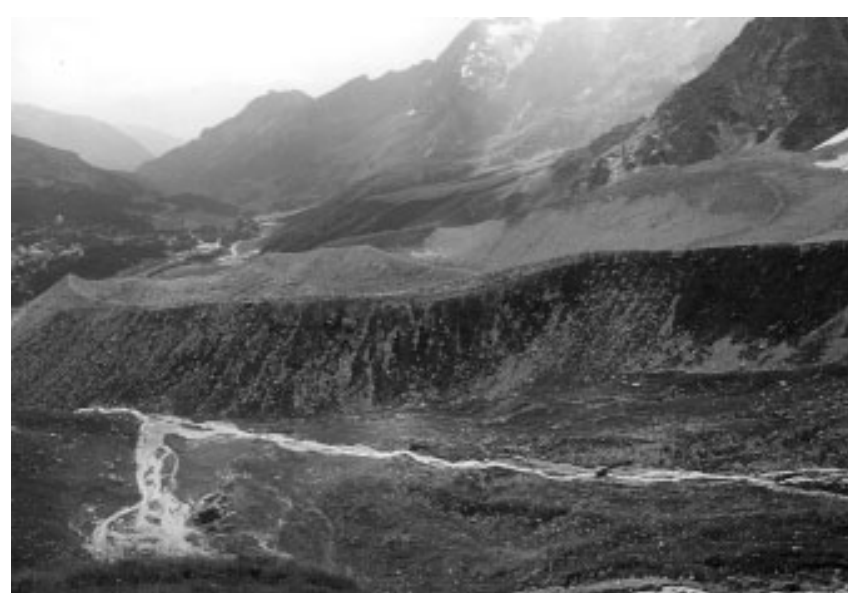

Fig. 7. The semicircular moraine of Cherillon glacier. The glacier flows from right to left (photo by C.Vanuzzo).

line. The glaciers studied covered $14.78 \mathrm{~km}^{2}$ during the LIA maximum, whereas the present glacierized area is $5.88 \mathrm{~km}^{2}$, a loss of $8.9 \mathrm{~km}^{2}$ equalling $60.22 \%$ (Table 2). The Valtournenche and Teódulo glaciers, which together with the now extinct Gran Sommetta glacier made up a large single glacierized mass during the LIA, contributed most to this retreat. At the LIA maximum they occupied $8.11 \mathrm{~km}^{2}$, but were reduced by $6.11 \mathrm{~km}^{2}$ to $2 \mathrm{~km}^{2}$, losing $75.34 \%$ of their area. Such a high value can be explained by the morphology of both the bedrock and the glaciers themselves. As a consequence of the low gradient and of a relatively large area near the equilibrium line altitude (ELA), even a small change in mass balance was capable of causing considerable ice retreat.

The subsequent retreat phases of the Valtournenche glacier were deduced from historical maps (Lesca and others, 1955) and are summarized in Figure 9. From early reports, it was also possible to reconstruct some stages of the recession of the Mont Tabel, Cherillon, Leone, Tyndall, Cervino-Forca and Teódulo-Valtournenche glaciers (Fig. 8). In total, the glaciers investigated in the upper Valpelline and Valtournenche valleys underwent a $42.34 \%$ retreat from their LIA maximum (1820) to the present (1981).

\section{VOLUME GHANGES OF THE VALPELLINE AND VALTOURNENGHE GLACIERS}

The use of a GIS has enabled volume changes affecting the Valpelline and Valtournenche glaciers to be calculated. By reconstructing the topography of each glacier during the LIA maximum, and by comparing it with the present situation,

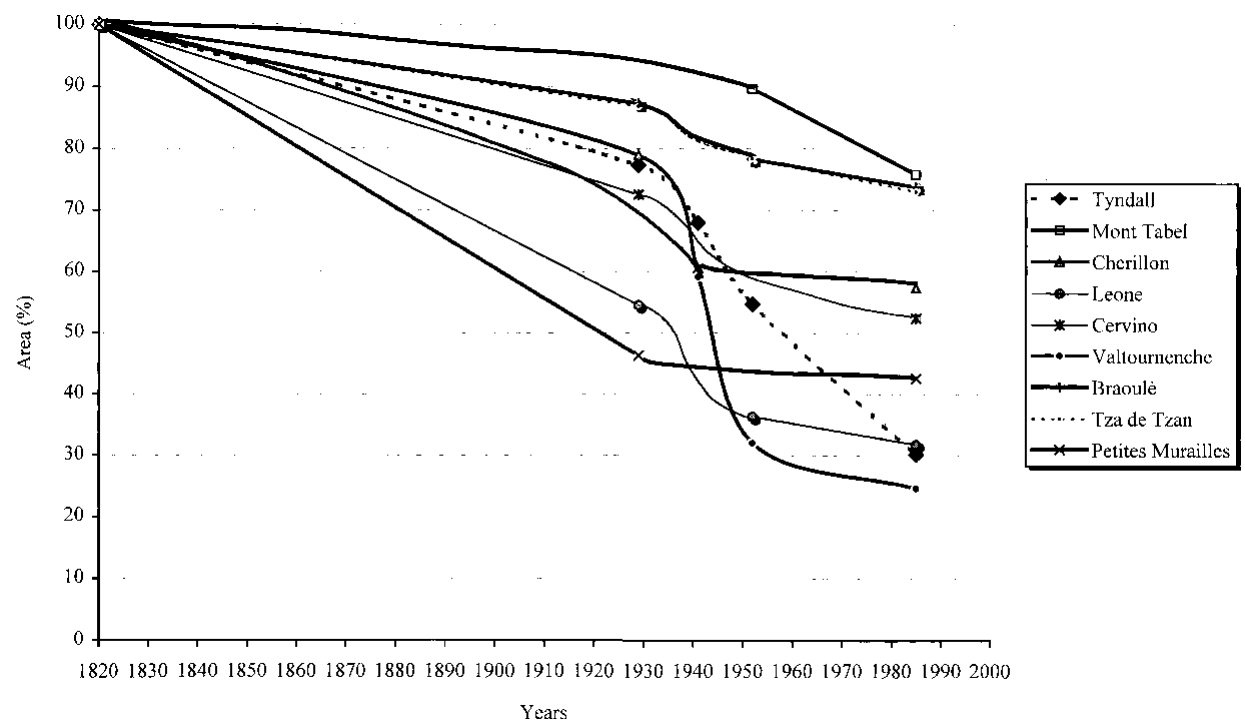

Fig. 8. Percentage areal retreat of some of the glaciers studied. For most, a fast retreat phase is evident from 1930-50, slowing from 1960-80. 


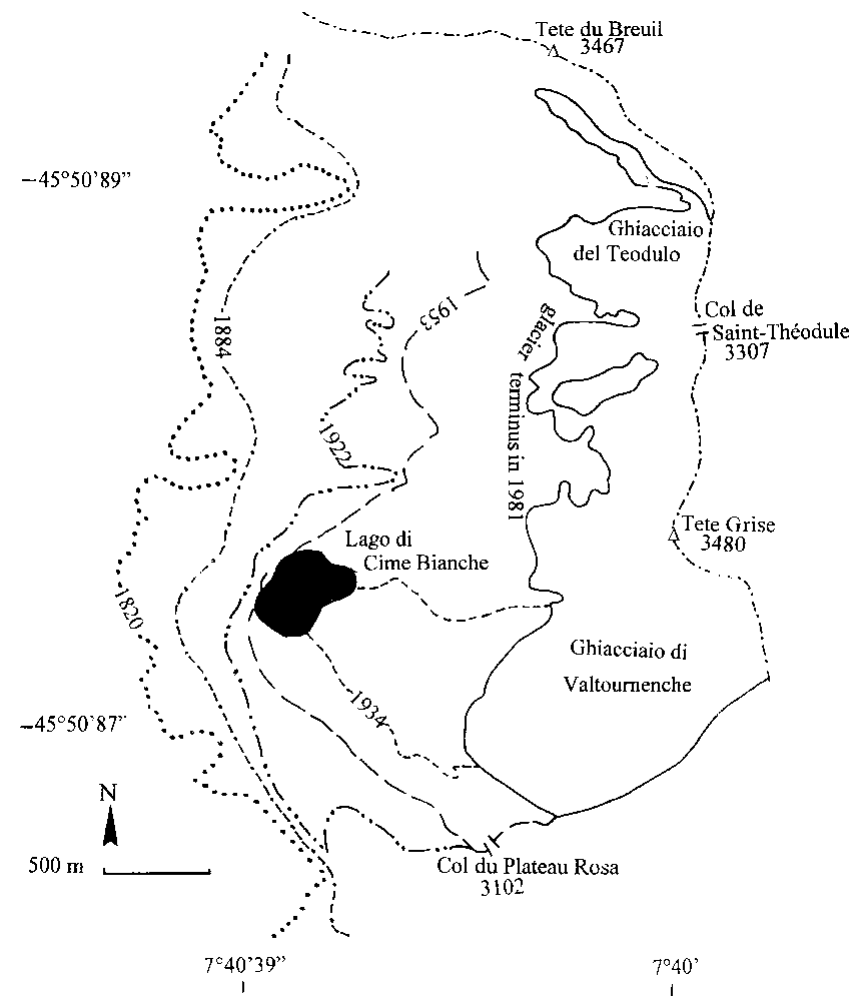

Fig. 9. Stages in the retreat of the Valtournenche glacier.

the volume difference over this period was assessed. Since no information is available on the bedrock, particularly ice thickness, the calculations were limited to the overall volume difference, not the total volume.

The data from the 17 glaciers analyzed show an ice-volume loss of $0.35 \mathrm{~km}^{3}$ from the LIA maximum to the present, equal to $0.315 \mathrm{~km}^{3}$ of water. Considering that the overall reduction in area of the glaciers studied was $14.78 \mathrm{~km}^{2}$, the average thickness of the ice melted must have been about $24 \mathrm{~m}$.

The values are certainly underestimated. In fact, in the reconstruction of the glaciers, the topography of their accumulation areas was considered unchanged; only the lower area, corresponding to the ablation zone, was reconstructed. Thus, in calculating the volume change, the loss of ice taking place in the accumulation zone, mainly a thinning, was not assessed.

\section{PALEOCLIMATIC GONSIDERATION}

The dynamic behaviour of a glacier depends on the temperature in the ablation season and on snowfall. The estimated mean annual temperature increase in Valle d'Aosta, from the LIA maximum to the present, is $0.8^{\circ} \mathrm{C}$. This value has been deduced from the ELA rise of 143 glaciers located in Valle d'Aosta (Vanuzzo, 1995).

\section{GONGLUSION}

The general recessional trend of Alpine glaciers is one of the most evident of Nature's indicators of the warming phase that started in the mid-19th century. The data here, even though local, confirm the trend generally observed for glaciers throughout Europe (Alps, Scandinavia), as regards areal, volumetric and linear retreat (Pelfini, 1996; Maisch, 1992; Haeberli and others, 1989).

For Alpine glaciers, the total loss of area, from 1850 to the mid-1970s, has been estimated at 50\% of the original value (Haeberli, 1995). For the 17 glaciers investigated here, the calculated value is $42.34 \%$. In the upper Valpelline, the glacierized area has gone from 20.13 to $14.78 \mathrm{~km}^{2}$, whereas for the upper Valtournenche a reduction from 14.78 to $5.8 \mathrm{~km}^{2}$ has been recorded. The estimated ice-volume loss was $0.35 \mathrm{~km}^{3}$.

\section{ACKNOWLEDGEMENTS}

The authors would like to thank G. Orombelli for his critical revision of the paper. The research was financed by the Murst 1997 programme: "Response of Geomorphological Processes to Environmental Changes" (national coordinator: A. Biancotti; local coordinator: G. Orombelli).

\section{REFERENCES}

Ahlmann, H.W. 1953. Glacier variations and climatic fluctuations. New York, American Geographical Society.

Frisa, A. 1956. Relazioni delle campagne glaciologiche 1955. Boll. Com. Glaciol. Ital., Ser. II 7, 125-129.

Grove, J. M. 1988. The Little Ice Age. London, Methuen and Co. Ltd.

Haeberli, W. 1995. Glacier fluctuations and climate change detectionoperational elements of a worldwide monitoring strategy. WMO Bull., 44(1), 23-31.

Haeberli, W., P. Müller, P. Alean and H. Bösch. 1989. Glacier changes following the Little Ice Age - a survey of the international data basis and its perspectives. In Oerlemans, J., ed. Glacier fluctuations and climatic change. Dordrecht, etc., Kluwer Academic Publishers, 77-101.

Table 1. Changes in area of the Valtournenche glaciers

\begin{tabular}{|c|c|c|c|c|c|}
\hline \multirow[t]{3}{*}{ Glaciers } & \multirow[t]{3}{*}{ Orientation } & \multicolumn{2}{|c|}{ Extent of glaciers } & \multicolumn{2}{|c|}{ Loss of area since LIA } \\
\hline & & $L I A$ & Present & & \\
\hline & & $\mathrm{km}^{2}$ & $\mathrm{~km}^{2}$ & $\mathrm{~km}^{2}$ & $\%$ \\
\hline Ghiacciaio di Mont Tabel & $\mathrm{S}$ & 1.16 & 0.88 & 0.28 & 24.14 \\
\hline Ghiacciaio di Cherillon & $\mathrm{S}$ & 1.90 & 1.09 & 0.81 & 42.63 \\
\hline Ghiacciaio del Leone Inferiore & $\mathrm{S}$ & 0.44 & 0.14 & 0.30 & 68.18 \\
\hline Ghiacciaio del Leone Superiore & $\mathrm{S}$ & 0.16 & 0.09 & 0.07 & 43.75 \\
\hline Ghiacciaio di Tyndall & $\mathrm{S}$ & 0.53 & 0.16 & 0.37 & 69.81 \\
\hline Ghiacciaio del Cervino-Forca & $\mathrm{S}$ & 2.48 & 1.52 & 0.96 & 38.71 \\
\hline Ghiacciaio Teódulo-Valtournenche & W & 8.11 & 2.00 & 6.11 & 75.34 \\
\hline Total & & 14.78 & 5.88 & 8.90 & 60.22 \\
\hline
\end{tabular}


Hoinkes, H.C. 1968. Glacier variation and weather. 7. Glaciol., 7 (49), 3-19.

Kuhn, M. 1981. Climate and glaciers. International Association of Hydrological Sciences Publication 131 (Symposium at Canberra 1979 - Sea Level, Ice and Climatic Change), 3-20.

Lesca, C., M. Vanni and F. de Gemini. 1955. Il Ghiacciaio di Valtournanche. Boll. Com. Glaciol. Ital., Ser. II 6, 33-78.

Maisch, M. 1992. Die Gletscher Graubündens: Rekonstruktionen und Auswertung der Gletscher und deren Veränderungen seit dem Hochstand von $1850 \mathrm{im}$ Gebiet der östlichen Schweizer Alpen (Bündnerland und angrenzende Regionen). Zürich, Universität Zürich. Geographisches Institut.

Nesje, A., M. Kvamme, N. Rye and R. Løvlie. 1991. Holocene glacial and climate history of the Jostedalsbreen region, western Norway; evidence from lake sediments and terrestrial deposits. Quat. Sci. Rev., 10(10), 87-114.

Oerlemans, J. 1989. On the response of valley glaciers to climatic change. In Oerlemans, J., ed. Glacier fluctuations and climatic change. Dordrecht, etc., Kluwer Academic Publishers, 353-371.

Orombelli, G. and S. Porter. 1982. Late Holocene fluctuations of Brenva glacier. Geogr. Fis. Din. Quat., 5(1), 14-37.

Pelfini, M. 1996. Surface area reduction and rise of the equilibrium-line on the Ortles-Cevedale glaciers (Lombardy, Italy) from the "Little Ice Age" to present. Riv. Geogr. Ital., 103, 63-71.

Porter, S. C. 1975. Equilibrium-line altitudes of Late Quaternary glaciers in the Southern Alps, New Zealand. Quat. Res., 5(1), 27-47.

Porter, S. C. 1981. Glaciological evidence of Holocene climatic change. In
Wigley, T.M.L., M.J. Ingram and G. Farmer, eds. Climate and history: studies of past climates and their impact on man. Cambridge, Cambridge University Press, 82-110.

Porter, S.C. 1986. Pattern and forcing of Northern Hemisphere glacier variations during the last millennium. Quat. Res., 26(1), 27-48.

Porter, S.C. and G.H. Denton. 1967. Chronology of neoglaciation in the North American Cordillera. Am. 7. Sci., 265(3), 177-210.

Revelli, P. 1917. Fronti glaciali della Valpellina (Valle d'Aosta) 1912-1916. Boll. Com. Glaciol. Ital., Ser. I 2, 25-41.

Röthlisberger, F. 1974. Étude des variations climatiques d'après l'histoire des cols glaciaires. Le Col d'Herens (Valais, Suisse). Boll. Com. Glaciol. Ital., Ser. II 22, 9-34.

Röthlisberger, F. 1986. 10000 Fahre Gletschergeschichte der Erde. Aarau, Verlag Sauerländer.

Vanni, M. 1939. Il Ghiacciaio di Tsa de Tsan in Valpelline. Boll. Com. Glaciol. Ital., Ser. I 19, 61-97.

Vanni, M. 1966. Relazioni della campagna glaciologica 1961. Boll. Com. Glaciol. Ital., Ser. II 12, 81-87.

Vanni, M., C. Origlia and F. de Gemini. 1953. I ghiacciai della Valle d'Aosta. Boll. Com. Glaciol. Ital., Ser. II 4, 1-172.

Vanuzzo, C. 1995. I ghiacciai come indicatori delle variazioni climatiche ed ambientali nella Valle d'Aosta: storia glaciale olocenica della Valpelline e della Valtournenche. (Ph.D. thesis, University of Milan.) 